\section{Difficulties in Justifying General Public Subsidies for Higher Education in Developing Countries}

\section{David E. Bloom and Jaypee Sevilla}

David Bloom is the Clarence James Gamble Professor of Economics and Demography at the Harvard School of Public Health and chairman of the Department of Population and International Health. Jaypee Sevilla is assistant professor of international health economics at the Harvard School of Public Health. Address: Department of Population and International Health, Harvard School of Public Health, 665 Huntington Avenue, Boston, Massachusetts 02115, USA. E-mail: dbloom@hsph.harvard.edu; jsevilla@hsph.harvard.edu.

$S^{1}$ hould the government offer at least a partial subsidy to everyone who attends higher education institutions in developing countries? We answer this question in three stages: (1) what would society gain from such a policy, (2) does the fact that higher education brings net social benefits imply a need for general subsidies, and (3) are the gains achievable by subsidies larger than those that could be obtained from alternative policies? In our conclusion we ask whether the state should promote higher education at all.

\section{What Does Society Gain?}

Society gains from a person's higher education if the total social benefits from this education are larger than the total social costs of producing it. Society's gain can be measured by the net social benefit, or the excess of the social benefits over social costs.

The costs and benefits of education are simple to enumerate. Social costs include everything that must be given up in order to produce the education. These include the resources that must go into paying for tuition, books, other educational expenses, and a student's ordinary living expenses such as food and housing. They also include the foregone income that the student could have earned by working instead of studying.

Social benefits include the private benefits enjoyed directly by the individual, such as higher earnings through life. But they also include public benefits, that is, benefits that society derives from higher education over and above those enjoyed by the individual himself or herself. These include having (a) a critical mass of wellinformed citizens who understand and work for democratic practices; (b) a larger pool of capable business people who can run more efficient businesses and ultimately expand the economic pie; (c) political leaders who can understand the confluence of local conditions and the fast-evolving international arena; and (d) scientists and technicians who can play key roles in appropriately adapting and integrating developedworld practices into a society's agricultural, industrial, and educational systems.

While estimates of the relative size of these costs and benefits are hard to come by, it is not unreasonable to assume that in many cases, the benefits are larger than the costs, so that on the whole, there are net social benefits to investments in higher education.

\section{Do Net Social Benefits Imply the Need for General Subsidies?} If we limit our attention to that part of the population that would bring about a net social benefit by going to school, and if we assume that the government's objective is only to make sure that these people enroll, we would conclude that there is no reason to subsidize those who would go to school of their own accord. The government should only subsidize those who are on the fence and for whom a subsidy would be the decisive factor in favor of enrolling. The appropriate target population for the subsidy therefore consists primarily of people who would produce a net gain for society through their higher education, but either do not have a strong enough private incentive to go to school, or cannot afford to do so.

\section{Society gains from a person's higher education if the total social benefits from this education are larger than the total social costs of producing it.}

The ideal solution to this problem is a targeted subsidy that directs funds only at people for whom the subsidy makes a decisive difference. The difficulty lies in our imperfect ability to distinguish between those for whom the subsidy is decisive and those who would go to school anyway. A general subsidy gets around this difficulty by subsidizing everyone, but at the cost of transferring scarce resources to people who would go to school anyway. This "leakage" yields no incremental social benefit since these people would do the socially beneficial action even in the absence of the subsidy and is potentially regressive since those who would go to school in any case tend to be those with sufficient financial means.

Therefore, though it is likely that investments in higher education produce net gains to society, this does not imply that general public subsidies are desirable. Targeted subsidies seem a more appropriate response, 
though they may entail difficulties in identifying the appropriate individuals to subsidize. Whether general subsidies produce a net social benefit therefore depends on the following factors: the net social gain from education in general, the relative size of the population for whom subsidies are decisive and those for whom subsidies are not, and lastly, the difficulties of targeting subsidies.

How does a General Subsidy Compare with Alternative Policies?

Even if, after considering the factors just cited, we conclude that a general subsidy is likely to produce a net social gain, we still do not have a sufficient argument for it. In a world of great social need and finite resources, many policies are likely to produce net social gains, and a general subsidy becomes a good idea if the gains produced compare favorably with those of alternative policies. This is a stringent requirement, and one we are not sure it can hurdle. Specifically, most governments will correctly see that investing in primary and secondary school education, primary health care, and HIV / AIDS prevention and treatment-to give only a few prominent examples-will give a much better return on public funds than will subsidizing higher education.

In the rare case of a public treasury having sufficient funds to engage in all attractive investments, it should do so. But normally, prioritizing will be necessary. It is not enough to say that a higher education subsidy would benefit the public. When other investments that would shore up the station in life of the ill-educated and the sick would be more useful, governments should not choose to subsidize higher education.

\section{Should the State Promote Higher Education at All?}

One might erroneously conclude, from what we have said, that we don't think the state should be supporting higher education at all. To be clear: we do think there is a public interest in higher education, above and beyond the benefits received by individual students. This public interest derives not only from the overall rise in the standard of living that increased educational levels bring to those who partake of such education, but from society-wide effects along the lines listed earlier: increased local capacity to create and absorb technology; a greater portion of the population attuned to the workings and advantages of democracy; improved health resulting from greater understanding of nutrition, disease, medicine and public health practices; an enhanced capacity to engage in international negotiations of all types; and strengthened links with other countries.
Indeed, these public benefits of higher education are key reasons why governments should take an active role in strengthening colleges and universities, encouraging changes in their governance structures, ensuring high-quality programs of study, offering guidance regarding the value of including a liberal education perspective within a more-focused set of studies, and promoting the study of science and technology. These benefits are discussed at greater length in Higher Education in Developing Countries: Peril and Promise, the product of an international task force convened by the World Bank and UNESCO.

The task at hand is daunting: resources are scarce and the need is great. But helping the well-off obtain higher education when many of them already manage to do so without government help does not make sense economically. And when governments are swamped with more pressing demands (which is virtually always the case), a general subsidy for higher education is not a good course of action.

A longer version of this article is available: "Should There Be a General Subsidy for Higher Education in Developing Countries?" by D. Bloom and J. Sevilla, in the Journal of Higher Education in Africa, forthcoming at the end of 2003.

\section{African Universities, International Donors, and the Public Good \\ Kenneth Prewitt}

Kenneth Prewitt is Carnegie Professor of Public Affairs at Columbia University. Address: School of International Affairs, IAB 1315, Columbia University, NY, NY 10027. E-mail: kp2058@columbia.edu.

$F^{o}$ or African universities, more than is the case elseFhere, depend for their survival on the scope and focus of external support. Current documents on university reform, and there are many, inevitably urge greater support from international donors. The heavy reliance on donor funds has been true since independence. As donors shifted from one model of university support to another, universities adapted accordingly. In the immediate postindependence period, the high-prestige national elite university was the accepted model. The university was to do nation-building by looking and feeling like the universities of the colonial powers. This period was followed by the development university phase with its emphasis on economic growth. When dis- 